Review

\title{
Clinical Tolerance Trials in Renal Transplantation - Where Do We Stand?
}

Joachim Andrassy ${ }^{1,}{ }^{*}$, Antje Habicht ${ }^{2}$

1. Department of Surgery, Ludwig-Maximilian's University, Munich, Germany; E-Mail: joachim.andrassy@med.uni-muenchen.de

2. Transplant Center, Ludwig-Maximilian's University, Munich, Germany; E-Mail: antje.habicht@med.uni-muenchen.de

* Correspondence: Joachim Andrassy; E-Mail: joachim.andrassy@med.uni-muenchen.de

Academic Editor: Jean Kwun

Special Issue: Multiple Aspects of Transplant Tolerance - Mechanisms, Strategies, and Barriers

OBM Transplantation

2019 , volume 3 , issue 2

doi:10.21926/obm.transplant.1902070
Received: November 05, 2018

Accepted: June 18, 2019

Published: June 27, 2019

\begin{abstract}
In recent years, the potential of hematopoietic stem cells, regulatory T-cells, and mesenchymal stem cells have brought about a variety of clinical tolerance trials. Every approach has yielded promising results; however, the riddle of transplant tolerance has not been solved as of yet. The results of the ongoing trials in this field will provide additional information regarding the risks and benefits of these therapy approaches.
\end{abstract}

\section{Keywords}

Clinical tolerance trials; renal transplantation; transplantation

\section{Introduction}

An allograft is recognized by the recipient's immune system as something foreign and potentially harmful. Depending on the immunogenicity (organ, HLA-mismatches, etc.) of the transplant and the immune status of the recipient, the innate and adaptive immune system are

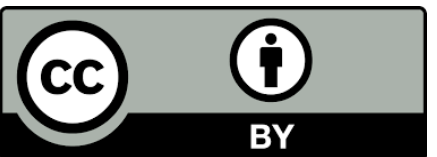

(C) 2019 by the author. This is an open access article distributed under the conditions of the Creative Commons by Attribution License, which permits unrestricted use, distribution, and reproduction in any medium or format, provided the original work is correctly cited. 
turned on to re-establish physical integrity. The severity of rejection extends from a slow "smoldering" process over years to a hyperacute reaction which destroys the organ within hours. Pharmacological immunosuppression attenuates this process. Unfortunately, the continuous immunosuppression comes at a price. Increased rates of infections and malignancy along with the problems of pharmacotoxicity result in considerable morbidity and mortality rates over time [1].

Transplant tolerance has occupied generations of researchers. Chimerism [2, 3], anergy [4], regulation [5], ignorance [6], exhaustion [7], clonal deletion [8], etc. have been described as potential mechanisms. A variety of cells (Tregs, Bregs, DCregs, Mregs, MSCs, etc.) were found responsible for transplant tolerance induction. A vast knowledge about the underlying processes has been compiled; however, tolerance in human transplantation is still not easily achieved, due to the complexity of the individuals' immune system.

Many of these important experimental findings have been tested in clinical trials, which are summarized in this article.

\section{Hematopoietic Stem Cells (HSC)}

One theory is that macrochimerism is required for a sustained transplant tolerance. Persistent macrochimerism is challenging to achieve and it is believed that hematopoietic stem cell transplantation (HSCTx) is mandatory for it. The concept of chimerism and tolerance goes back to the work by Owen et al. and Billingham et. al. more than half a century ago [2, 3].

The first renal transplantations in combination with HSCTx from the same donor reach back into the 80s. Three US centers had the pioneering role. Massachusetts General Hospital (MGH) began its first clinical trial in 1998 [9, 10]. Stanford University followed in 2000 [11] and Northwestern University in 2009 [12]. Thus, these regimens are also known as the "Massachusetts General Hospital (MGH)-", "Stanford-“, and "Northwestern-" approaches.

\subsection{Massachusetts General Hospital}

Three modifications of the original conditioning regimen were used on $n=10$ patients receiving HLA-haploidentical living related renal transplants [9]. The original regimen included pretransplant cyclophosphamide, thymic irradiation, anti-CD2 mAB, and CsA-immunosuppression. Unprocessed donor bone marrow was infused intravenously after the transplantation. After the first 3 patients, the regimen was modified with the addition of rituximab and prednisone. Since the next two patients still developed DSAs, the regimen was again modified with more doses of rituximab and a prolonged course of prednisone. All patients developed transient multilineage mixed chimerism. Only 2-3 weeks after the combined kidney and bone marrow transplantation (CKBMT), the chimerism became undetectable again. Immunosuppression was withdrawn by month 14 after the transplantation. According to the latest report, 4 of the 10 patients remained off immunosuppression greater than 13 years. Another 3 patients were started again on immunosuppression after 5,7 , and 8 years and immunosuppression could not be stopped in the remaining three patients.

Unexpectedly, almost all of these patients (9/10) developed acute kidney injury. The pathogenesis remains unclear. The authors observed hematopoietic cell recovery and rapid loss of chimerism along with the AKI episodes. Consecutively, the regimen was changed again. Instead of 
the cyclophosphamide, a low-dose TBI was introduced. Two patients have been treated with this regimen, and one was taken off of immunosuppression.

\subsection{Stanford}

This conditioning protocol consists of total lymphocyte irradiation (TLI), rabbit anti-thymocyte globulin (rbATG), followed by an infusion of CD34+-enriched donor peripheral blood stem cells [13]. The patients were started on a combination of Calcineurininhibitors (CNI)/mycophenolate mofetil (MMF) and steroids until weaning was attempted several months later. Here, TLI implies irradiation of the lymph nodes, spleen, and thymus with several small doses of irradiation. This has been shown to create a regulatory milieu with an increased ratio towards Tregs, myeloid-derived suppressor cells, and tolerogenic dendritic cells.

The total irradiation dose is much smaller compared to those doses used to treat cancer (20$25 \%)$. Thus, tolerability is much better and there is no risk for graft versus host disease.

Two trials of the protocol exist, one for HLA-matched and the other for HLA-mismatched patients. The HLA-matched trial included 29 patients of which 23 achieved multi-lineage, mixed macrochimerism. Twenty-two of the 23 enjoyed rejection-free transplant kidney survival, up to nine years off drugs. Macrochimerism could no longer be detected after the first year in 14 patients.

The HLA-mismatched trial began in 2000 and was stopped in 2003. In this period 6 patients were treated by this regimen but only 2 developed mixed chimerism and were deemed appropriate candidates for immunosuppression withdrawal. These two stayed off immunosuppression for 3.5 and 5.5 months when they developed acute rejection. The current version started in $2010[11,13]$. Compared to the HLA-matched trial, patients received a more powerful immunosuppression over a longer period post transplantation. Furthermore, TLI dosage is higher and more CD3+ cells are added back. Since 2010, only haplotype matched pairs were included. Macrochimerism can also be seen under this regimen. However, it is dependent on continued immunosuppression. Consecutively, of the $n=21$ patients treated with this regimen, only a few could be withdrawn off immunosuppressive drugs, and this only for a limited time.

\subsection{Northwestern}

For HLA-mismatched renal transplant patients, the tolerance induction regimen includes total body irradiation (TBI; $200 \mathrm{cGy}$ ). The patients are preconditioned with fludarabine cyclophosphamide. Also, a "facilitating cell (FC)" (CD8+/TCR-) is infused and patients receive cylcophosphamide which deletes antihost $T$ cells thus protecting against GVHD. The human FC population is composed of two equally divided phenotypic subpopulations: CD56bright and CD56dim FC [14]. Immunosuppression was stopped if patients showed chimerism, had stable renal function with a normal protocol biopsy, and absence of donor specific antibodies 6 months after the transplantation. Patients were weaned over 1 year. In 2009 a phase 2 trial was started to induce tolerance in mismatched and unrelated recipients of living donor renal allografts. The latest publication reported on 42 subjects which had been enrolled since then [15]. Of these, $n=37$ had been transplanted and $n=31$ had already reached one year follow-up. $N=23$ achieved durable donor chimerism. The majority of them (20/23) showed full (>95\%) whole blood and T cell chimerism and the remaining three demonstrated stable mixed donor chimerism. 
Immunosuppression was stopped in $n=22$ of the 23 durably chimeric patients for a duration ranging from 8-81 months so far.

The regimen for HLA-matched kidney transplant recipients consists of alemtuzumab, donor HSCs (DHSCS), TAC, and MMF. Four DHSC infusions are administered; on day 5, and month 3, 6 and 9 after the transplantation. TAC is converted to SRL at month 3 with an attempted drug withdrawal at 24 months post transplantation with a weaning process over 1 year in case protocol biopsies remained free from rejection. The latest update reported on 20 patients included in this trial so far. Of these, $n=6$ remain off immunosuppression up to $6 \mathrm{yrs}$. None of the patients maintained durable chimerism after 1 year [16].

\section{Regulatory T-Cells (Tregs)}

CD4+CD25+ $T$ cells have been shown to have a regulatory property in self-tolerance and autoimmune diseases [5]. The identification of the FOXP3 gene helped to characterize them and to investigate their function [17]. FOXP3 knockout mice demonstrate a regulatory T cell (Treg) deficit leading to autoimmune syndromes, and a FOXP3 mutation leads to an autoimmune disorder in humans [18], while the addition of a FOXP3 transgene in immunodeficient mice can restore the regulatory $T$ cell compartment. Tregs are divided into two groups: naturally occurring Tregs (nTregs) generated in the thymus and inducible Tregs (iTregs) produced upon antigen stimulation in the periphery [19]. The mechanism of Treg function depends on the immune environment, their activation state, and target cell type. Tregs suppress the immune responses by:

1.) modulation of dendritic cell function or maturation,

2.) release of inhibitory cytokines,

3.) cytolysis, and

4.) metabolic disruption.

In transplantation their suppressive capacity can depend on donor-specificity [20-22]. In animal models, donor alloantigen-specific Tregs are 5-10 times more effective than polyclonal Tregs with the efficacy corresponding to the frequency of donor-specific Tregs in the polyclonal pool [23]. They are capable of suppressing effector $T$ cells of various specificities and Tregs can induce a process that is called "infectious tolerance". Tregs specific for alloantigen A can suppress effector $T$ cells against alloantigen $B$, if the graft expresses alloantigen $A$ and $B$. Over time, alloantigenspecific $A$ and $B$ Tregs expand and persist much longer than the originally infused Tregs [24]. These preclinial data suggest that adoptive transfer of Treg cells in transplantation might be an attractive approach to induce operational tolerance. Treg numbers can be either increased by infusion of iTregs or by promoting endogenous nTreg expansion. It was only logical that Tregs were used to achieve transplant tolerance.

Until today only a few Treg studies have entered clinical trials due to costs, availability and applicability of cells, and the need for GMP facilities. It is unclear which subsets and dosage of Tregs are necessary for therapy and which time point is optimal for infusion in terms of function and stability. The isolation of suppressive Treg cell populations is complicated. FOXP3 is an intracellular marker and thus cannot be used for isolation. CD25 is not only expressed on Tregs but also on activated effector T cells. Therefore, contamination with non-Tregs, such as effector cells, is possible, when using Treg isolation for clinical cell therapy. Other markers are needed, such as CD127, the $\alpha$-chain of the IL-17 receptor, which has been described to deliver a highly suppressive 
Treg population when used together with CD4 and CD25 [25-29]. Other problems are durable stability and that Tregs can lose their suppressive function and even differentiate into effector $T$ cells.

Adoptive transfer of ex vivo generated anti-donor iTregs allowed long-term graft survival after renal transplantation in non-human primates [30]. nTregs were already used with varying success in graft-versus-host disease (GvHD) [31, 32] and prevention of type 1 diabetes [33].

Several trials are ongoing, but so far only three centers have successfully completed and published clinical data using expanded recipient Tregs in the context of solid organ transplantation (SOT) [34-36] (Table 1).

The Pilot Trial of Polyclonal Treg Adoptive Therapy for Control of Subclinical Transplant Inflammation [34] assessed the safety and feasibility of injecting $\mathrm{CD} 4^{+} \mathrm{CD} 25^{+} 127^{-}$peripheral blood Tregs $\left(320 \times 10^{6}\right.$ cells) that were FACS-sorted and expanded polyclonally ex vivo into kidney transplant recipients with subclinical inflammation on a 6-month protocol biopsy. This regimen revealed mixed results. In $n=2$ patients, graft inflammation and rejection scores were improved with no incidence of acute rejection. Another patient had signs of subclinical acute cellular rejection 6 months after Treg infusion. Based on these preliminary data the group has recently initiated the TASK trial (NCT02088931) to compare the efficacy of infused polyclonal Tregs versus donor alloantigen-reactive Tregs in kidney transplant recipients with subclinical inflammation. The trial protocol is to infuse 400 million \pm 100 million Tregs into each patient. The cohort will consist of 45 recipients of living-donor kidneys who exhibit graft inflammation based on protocol biopsy at 6 months after transplant. This trial aims to answer some important questions related to:

1.) safety and tolerability of polyclonal and donor alloantigen-reactive Treg infusions,

2.) where these cells finally accumulate, and

3.) if they will eventually control the inflammatory process [24].

A Phase I Clinical Trial with Ex Vivo Expanded Recipient Regulatory T cells in Living Donor Kidney Transplants (TRACT) investigated the safety of the transfer of autologous, polyclonally expanded Tregs in 9 living donor kidney transplant recipients. nTregs were isolated by $\mathrm{CD} 25^{+}$enrichment, $\mathrm{CD}^{+}$and $\mathrm{CD}_{19}{ }^{+}$depletion and expansion with anti-CD3/CD28-coated beads, IL-2, and sirolimus over 3 weeks. Cells were used for infusion when the percentage of $\mathrm{CD} 4^{+} \mathrm{CD} 25^{+}$cells was greater than $70 \%, \mathrm{CD}^{+}$and $\mathrm{CD} 19^{+}$cells less than $10 \%$, and suppression of Teff proliferation in vitro greater than $50 \%$. Prior to the Treg infusion, lymphodepletion in the recipients was induced by alemtuzumab. Patients received TAC and MMF-based immunosuppression followed by conversion to SRL 30 days post-transplantation, in an effort to increase Treg survival.

This regimen successfully increased circulating $C D 4^{+} \mathrm{CD} 25^{\mathrm{hi}} \mathrm{CD} 127^{-} \mathrm{FOXP3}{ }^{+}$Tregs in the peripheral blood. In addition, patients did not develop rejection or serious adverse effects.

An abstract has been published on another attempt of an adoptive transfer of self-anergic cells in 12 kidney transplant recipients from HLA-mismatched living donors. In this study, recipient and donor PBMCs obtained by lymphocytapheresis were co-cultured in the presence of antiCD80/CD86 mAb and infused 12 days after transplantation as immunosuppression was gradually tapered. The patients received a splenectomy or rituximab and cyclophosphamide. The results were mixed. Incidence of biopsy-proven acute rejections (BPAR) was high. Therefore, immunosuppressive therapy was not completely withdrawn. Nonetheless, all 12 recipients had continuing transplant function. Follow-up data on $n=40$ renal transplant recipients who were treated with rituximab and rATG instead of cyclophosphamide have yet to be reported [37]. 
Table 1 Trials on Tregs in the context of solid organ transplantation (http://clinicaltrials.gov).

\begin{tabular}{|c|c|c|c|c|c|c|c|c|}
\hline NCT Number & Status & Titel & Conditions & Interventions & Phase & Enrolled & Time & Locations \\
\hline NCT01624077 & Unknown $^{+}$ & $\begin{array}{l}\text { Safety Study of } \\
\text { Using Regulatory T } \\
\text { Cells Induce Liver } \\
\text { Transplantation } \\
\text { Tolerance }\end{array}$ & $\begin{array}{l}\text { Chronic } \\
\text { Rejection } \\
\text { Liver Tx }\end{array}$ & Regulatory T cells & 1 & 1 & $\begin{array}{l}12 / 14- \\
12 / 15\end{array}$ & $\begin{array}{l}\text { Nanjing Medical } \\
\text { University } \\
\text { Nanjing, China }\end{array}$ \\
\hline NCT02188719 & Recruiting & $\begin{array}{l}\text { Donor-Alloantigen- } \\
\text { Reactive Regulatory } \\
\text { T Cell (darTregs) in } \\
\text { Liver } \\
\text { Transplantation }\end{array}$ & Liver Tx & darTreg Infusion & I & 24 & $\begin{array}{l}12 / 14- \\
01 / 22\end{array}$ & $\begin{array}{l}\text { University of } \\
\text { California, } \\
\text { San Francisco, US } \\
\text { Northwestern } \\
\text { University } \\
\text { Chicago, US } \\
\text { Mayo Clinic, } \\
\text { Rochester, US }\end{array}$ \\
\hline NCT02474199 & Recruiting & $\begin{array}{l}\text { Donor-Alloantigen- } \\
\text { Reactive Regulatory } \\
\text { T Cell (darTregs) for } \\
\text { Calcineurin Inhibitor } \\
\text { (CNI) Reduction } \\
\text { (ARTEMIS) }\end{array}$ & Liver Tx & darTreg Infusion & $\mathrm{I} / \mathrm{II}$ & 18 & $\begin{array}{l}09 / 15- \\
06 / 19\end{array}$ & $\begin{array}{l}\text { University of } \\
\text { California, } \\
\text { San Francisco, US } \\
\text { Northwestern } \\
\text { University } \\
\text { Chicago, US } \\
\text { Mayo Clinic, } \\
\text { Rochester, US }\end{array}$ \\
\hline NCT02088931 & Unknown ${ }^{\dagger}$ & $\begin{array}{l}\text { Treg Adoptive } \\
\text { Therapy for } \\
\text { Subclinical } \\
\text { Inflammation in } \\
\text { Kidney } \\
\text { Transplantation }\end{array}$ & $\begin{array}{l}\text { Late } \\
\text { Complication } \\
\text { Kidney Tx }\end{array}$ & Treg infusion & 1 & 3 & $\begin{array}{l}03 / 14- \\
12 / 16\end{array}$ & $\begin{array}{l}\text { University of } \\
\text { California, } \\
\text { San Francisco, US }\end{array}$ \\
\hline
\end{tabular}




\begin{tabular}{|c|c|c|c|c|c|c|c|c|}
\hline & & (TASK) & & & & & & \\
\hline NCT02091232 & $\begin{array}{l}\text { Active, not } \\
\text { recruiting }\end{array}$ & $\begin{array}{l}\text { Infusion of T- } \\
\text { Regulatory Cells in } \\
\text { Kidney Transplant } \\
\text { Recipients (The ONE } \\
\text { Study) }\end{array}$ & Kidney Tx & $\begin{array}{l}\text { Regulatory Cell } \\
\text { Infusion }\end{array}$ & I & 8 & $\begin{array}{l}05 / 14- \\
05 / 18\end{array}$ & $\begin{array}{l}\text { Massachusetts } \\
\text { General Hospital, } \\
\text { Boston, US }\end{array}$ \\
\hline NCT03444064 & Recruiting & $\begin{array}{l}\text { PolyTreg } \\
\text { Immunotherapy in } \\
\text { Islet Transplantation }\end{array}$ & Islet Tx & PolyTregs & I & 18 & $\begin{array}{l}02 / 18- \\
03 / 21\end{array}$ & $\begin{array}{l}\text { University of } \\
\text { Alberta, } \\
\text { Edmonton, Canada }\end{array}$ \\
\hline NCT02244801 & Completed & $\begin{array}{l}\text { Donor-Alloantigen- } \\
\text { Reactive Regulatory } \\
\text { T Cell (darTreg) } \\
\text { Therapy in Renal } \\
\text { Transplantation (The } \\
\text { ONE Study) }\end{array}$ & Kidney Tx & darTreg infusion & I & 6 & $\begin{array}{l}04 / 15- \\
08 / 18\end{array}$ & $\begin{array}{l}\text { University of } \\
\text { California, San } \\
\text { Francisco } \\
\text {, US }\end{array}$ \\
\hline NCT02129881 & Unknown † & $\begin{array}{l}\text { The ONE Study UK } \\
\text { Treg Trial }\end{array}$ & $\begin{array}{l}\text { End-stage } \\
\text { Renal Failure }\end{array}$ & $\begin{array}{l}\text { Autologous } \\
\text { regulatory T Cell }\end{array}$ & $I / I I$ & 12 & $\begin{array}{l}04 / 14- \\
03 / 17\end{array}$ & $\begin{array}{l}\text { Guy's Hospital, } \\
\text { London, UK } \\
\text { The Oxford } \\
\text { Transplant Centre, } \\
\text { Oxford, UK }\end{array}$ \\
\hline NCT02711826 & Recruiting & $\begin{array}{l}\text { Treg Therapy in } \\
\text { Subclinical } \\
\text { Inflammation in } \\
\text { Kidney Tx }\end{array}$ & Kidney Tx & $\begin{array}{l}\text { Polyclonal } \\
\text { Regulatory T Cells }\end{array}$ & $\mathrm{I} / \mathrm{II}$ & 45 & $\begin{array}{l}05 / 16- \\
10 / 21\end{array}$ & $\begin{array}{l}\text { University of } \\
\text { Alabama, } \\
\text { Birmingham, US } \\
\text { University of } \\
\text { California, San } \\
\text { Francisco, US } \\
\text { University of } \\
\text { Michigan, } \\
\text { Ann Arbor, US } \\
\text { and } 3 \text { more }\end{array}$ \\
\hline
\end{tabular}


OBM Transplantation 2019; 3(2), doi:10.21926/obm.transplant.1902070

\begin{tabular}{|c|c|c|c|c|c|c|c|c|}
\hline NCT02145325 & $\begin{array}{l}\text { Active, not } \\
\text { recruiting }\end{array}$ & $\begin{array}{l}\text { Trial of Adoptive } \\
\text { Immunotherapy } \\
\text { With TRACT to } \\
\text { Prevent Rejection in } \\
\text { Living Donor Kidney } \\
\text { Transplant } \\
\text { Recipients }\end{array}$ & Kidney Tx & Expanded Tregs & I & 10 & $\begin{array}{l}04 / 14- \\
12 / 21\end{array}$ & $\begin{array}{l}\text { Northwestern } \\
\text { University Chicago, } \\
\text { US }\end{array}$ \\
\hline NCT02371434 & Unknown ${ }^{+}$ & $\begin{array}{l}\text { The ONE Study } \\
\text { nTreg Trial } \\
\text { (ONEnTreg13) }\end{array}$ & Kidnex Tx & $\begin{array}{l}\text { autologous } \\
\text { CD4+CD25+FoxP3 } \\
+ \text { nTregs }\end{array}$ & $\mathrm{I} / \mathrm{II}$ & 9 & $\begin{array}{l}01 / 15- \\
12 / 17\end{array}$ & $\begin{array}{l}\text { Charité University } \\
\text { Medicine, } \\
\text { Berlin, Germany }\end{array}$ \\
\hline NCT03654040 & $\begin{array}{l}\text { Not yet } \\
\text { recruiting }\end{array}$ & $\begin{array}{l}\text { Liver } \\
\text { Transplantation } \\
\text { With Tregs at UCSF }\end{array}$ & Liver Tx & arTreg & $1 / I I$ & 9 & $\begin{array}{l}10 / 18- \\
12 / 25\end{array}$ & $\begin{array}{l}\text { University of } \\
\text { California, San } \\
\text { Francisco, US }\end{array}$ \\
\hline NCT03577431 & $\begin{array}{l}\text { Not yet } \\
\text { recruiting }\end{array}$ & $\begin{array}{l}\text { Liver } \\
\text { Transplantation } \\
\text { With Tregs at MGH }\end{array}$ & Liver Tx & arTreg-CSB & $1 / I I$ & 9 & $\begin{array}{l}10 / 18- \\
12 / 25\end{array}$ & $\begin{array}{l}\text { Massachusetts } \\
\text { General Hospital, } \\
\text { Boston, US }\end{array}$ \\
\hline NCT02085629 & Recruiting & The One M Reg Trial & ESRD & Donor $\mathrm{M}$ reg & $\mathrm{I} / \mathrm{II}$ & & $\begin{array}{l}07 / 14- \\
12 / 18\end{array}$ & $\begin{array}{l}\text { University Hospital } \\
\text { Regensburg, } \\
\text { Regensburg, } \\
\text { Germany }\end{array}$ \\
\hline
\end{tabular}


The EU-funded ONE Study is a consortium of six clinical trials which aim to investigate the safety and therapeutic efficacy of a variety of immunoregulatory cell therapies in living donor renal transplantation in comparison to a reference group. The study includes centers in the UK, Germany, France, Italy, and the US. The manufactured cells consist of polyclonal (UK group of King's College London and Oxford University (NCT02129881) and Charité-Universitätsmedizin Berlin (NCT02371434)) and alloantigen-specific nTregs (UCSF, San Francisco (NCT02244801) and MGH Boston (NCT02091232)), Tr1 cells, tolerogenic dendritic cells, and regulatory macrophages. At all of the participating sites, Tregs are infused within the first 10 days after transplant. Both groups, the one receiving the cellular therapy and the reference group will receive low dose tacrolimus, MMF, and steroids, with the reference group receiving anti-CD25 antibody induction instead of cellular infusion. The consortium has treated more than 35 patients in total and all sites have completed enrollment.

Having proven the safety and feasibility of Treg-based immunotherapy in the ONE Study (trial identifier: ONETreg1; ClinicalTrials.gov number: NCT02129881; EudraCT number: 2013-002099-42, co-sponsored by King's College London and Guy's and St Thomas' NHS Foundation Trust, REC number 13/SC/0568), the TWO Study aims to demonstrate the efficacy of this treatment, with the goal of allowing reduction of immunosuppression to a single drug by 6 -months posttransplantation.

\section{Mesenchymal Stem Cells (MSC)}

Mesenchymal Stem Cells (MSC) are a heterogeneous population of non-hematopoietic multipotent cells. In 2004 the potent immunosuppressive effects of in vitro culture-expanded MSC isolated from human bone marrow (BM) were shown for the first time in a clinical setting [38]. Therefore, most of the ensuing research was done on cells retrieved from the bone marrow. Over the following years MSCs could be found in almost all adult organs and tissues [39]. Identification of these cells is not easy because unique markers are lacking. More than 10 years ago, the "International Society for Cellular Therapy" defined 3 minimal criteria for MSCs: 1.) plastic adherence under standard culture conditions, 2.) expression of CD105, CD73, and CD90 molecules, and no expression of CD45, CD34, CD19 and CD79, and 3.) in vitro, the cells must have the capacity to differentiate into chondrocytes, osteoblasts, and adipocytes [40]. These criteria remain accepted to today.

MSCs express low levels of MHC class I molecules, but no MHC class II molecules or costimulatory molecules including CD80, CD86, and CD40, resulting in a lack of immunogenicity.

After infusion, MSCs preferentially home at the site of vascular damage or inflammation. This property may help diminish ischemia-reperfusion-injury, rescue marginal donor organs, and reduce alloimmune responses [41].

MSCs possess immunomodulatory properties by affecting the effector functions of cells of the innate and adaptive immune systems, by direct cell contact and release of soluble molecules. In multiple experimental settings, MSCs were shown to induce tolerance by different mechanisms. Modulation of the phenotype of antigen presenting cells with reduced cytokine production and suppression of $\mathrm{T}$ cell proliferation, shifting the alloimmune response towards regulation, have been described [42-44]. 
So far, over 500 clinical trials (http://clinicaltrials.gov/) have been registered since 2004. MSCs are being used for the treatment of many inflammatory disorders, including inflammatory bowel disease, rheumatoid arthritis, diabetes mellitus, and graft versus host disease (GvHD) [45]. However, only 6 MSC clinical trials in kidney transplantation have been published, which mainly focused on safety and feasibility. Currently, there are ongoing clinical trials with the aim to promote tolerance and to improve graft survival with minimization of immunosuppression (Table 2).

The challenges in clinical trials with adoptive transfer of MSCs include the source, dose, route, timing, decision of concomitant immunosuppression, and cost. MSCs for clinical applications should be manufactured in GMP facilities to ensure quality and reproducibility. However, protocols are not uniform yet. MSCs have been taken from different sources (mainly bone marrow, adipose tissue, or an umbilical cord) with different culture conditions. The published studies in renal transplantation have used BM-derived cells. The correct dose has yet to be found. Cells have been administered intravenously for most clinical studies. This has been shown to be safe but MSCs can also be injected directly into the kidney or underneath the kidney capsula with the advantage of direct homing and no entrapment in the lungs. Finally, concomitant pharmacological immunosuppression should be carefully chosen. Mycophenolate mofetil (MMF) and Rapamycin were shown to work synergistically along with MSCs in various transplant settings $[46,47]$.

In a recent renal transplant study, treatment with autologous BM derived MSCs $\left(1-2 \times 10^{6} / \mathrm{kg}\right.$ at kidney reperfusion and two weeks after transplantation) resulted in a reduced incidence of acute rejection $(7.7 \%$ vs. $21.5 \%)$, opportunistic infections, and better estimated glomerular filtration rate at 1 year as compared to controls $(n=51)$ receiving anti-IL-2 receptor antibody and standard dose CNIs [48]. Another trial showed that the combination of autologous bone marrowderived MSCs and a maintenance immunosuppressant reduces acute rejection and interstitial fibrosis/tubular atrophy up to 24 weeks after MSC infusion [49]. In a follow-up trial in 70 renal transplant recipients, the authors currently investigate if MSCs in combination with everolimus can facilitate tacrolimus withdrawal and reduce fibrosis (NCT02057965). A beneficial effect of the injection of autologous MSCs along with a maintenance immunosuppressant on the graft function one year post transplantation could also be demonstrated by Perico et al [50].

Timing of the infusion of MSC seems important, because MSC therapy early after transplantation negatively affected kidney graft function, which was not the case when MSCs were given before transplantation [51]. An interesting approach was chosen by Vanikar et al. who combined adipose-derived mesenchymal stem cells (AD-MSCs) with hematopoietic stem cells (HSC) and could show that the combination of the two indeed performed more effectively than HSC transplantation alone [52]. A cell therapy with HSC led to persistent mixed chimerism in about $1.8 \%$ of patients compared to $4 \%$ using combined AD-MSC + HSC in live donor kidney recipients with a higher incidence of rejections in the HSC only group. In a 5.7 year follow-up, graft and patient survival was $70 \%$ with $50 \%$ of patients on zero conventional immunosuppression and $20 \%$ on "rescue immunosuppression" (MPA plus steroid). 
Table 2 Trials on MSC in the context of solid organ transplantation (http://clinicaltrials.gov).

\begin{tabular}{|c|c|c|c|c|c|c|c|c|}
\hline NCT Number & Status & Title & Conditions & Interventions & Phase & Population & Time & Locations \\
\hline NCT02409940 & $\begin{array}{l}\text { Active, not } \\
\text { recruiting }\end{array}$ & $\begin{array}{l}\text { To Elucidate the Effect of } \\
\text { Mesenchymal Stem Cells } \\
\text { on the T Cell Repertoire of } \\
\text { the Kidney Transplant } \\
\text { Patients }\end{array}$ & $\begin{array}{l}\text { Kidney Tx } \\
\text { Rejection }\end{array}$ & MSC & I & 17 & $\begin{array}{l}09 / 13 \\
- \\
05 / 17\end{array}$ & $\begin{array}{l}\text { Translational and } \\
\text { Regenerative } \\
\text { Medicine, } \\
\text { Chandigarh, India }\end{array}$ \\
\hline NCT02561767 & $\begin{array}{l}\text { Unknown } \\
\text { status }\end{array}$ & $\begin{array}{l}\text { Effect of BM-MSCs in DCD } \\
\text { Kidney Transplantation }\end{array}$ & $\begin{array}{l}\text { Kidney Tx } \\
\text { ATN }\end{array}$ & BM-MSCs & $1 / 11$ & 120 & $\begin{array}{l}10 / 15 \\
- \\
10 / 17\end{array}$ & $\begin{array}{l}\text { Sun Yat-sen } \\
\text { University, } \\
\text { Guangdong, China }\end{array}$ \\
\hline NCT00752479 & Terminated & $\begin{array}{l}\text { Mesenchymal Stem Cells } \\
\text { Under Basiliximab/Low } \\
\text { Dose RATG to Induce Renal } \\
\text { Transplant Tolerance }\end{array}$ & Kidney Tx & MSC & $1 / 11$ & 4 & $\begin{array}{l}\text { 05/06 } \\
- \\
12 / 13\end{array}$ & $\begin{array}{l}\text { Nephrology Unit, } \\
\text { Bergamo, Italy }\end{array}$ \\
\hline NCT02563340 & $\begin{array}{l}\text { Unknown } \\
\text { status }\end{array}$ & $\begin{array}{l}\text { Effect of BM-MSCs on } \\
\text { Chronic AMR After Kidney } \\
\text { Transplantation }\end{array}$ & Kidney Tx & BM-MSCs & $1 / 11$ & 60 & $\begin{array}{l}11 / 15 \\
- \\
11 / 17 \\
\end{array}$ & $\begin{array}{l}\text { Sun Yat-sen } \\
\text { University, } \\
\text { Guangzhou, China }\end{array}$ \\
\hline NCT02490020 & $\begin{array}{l}\text { Enrolling by } \\
\text { invitation }\end{array}$ & $\begin{array}{l}\text { A Perspective Multicenter } \\
\text { Controlled Study On } \\
\text { Application Of } \\
\text { Mesenchymal Stem } \\
\text { Cell(MSC) To Prevent } \\
\text { Rejection After Renal } \\
\text { Transplantation By } \\
\text { Donation After Cardiac } \\
\text { Death }\end{array}$ & $\begin{array}{l}\text { Kidney Tx } \\
\text { Rejection }\end{array}$ & MSC & 1 & 20 & $\begin{array}{l}01 / 16 \\
- \\
12 / 18\end{array}$ & \\
\hline
\end{tabular}




\begin{tabular}{|c|c|c|c|c|c|c|c|c|}
\hline NCT02563366 & $\begin{array}{l}\text { Unknown } \\
\text { status }\end{array}$ & $\begin{array}{l}\text { Effect of BM-MSCs on Early } \\
\text { Graft Function Recovery } \\
\text { After DCD Kidney } \\
\text { Transplant. }\end{array}$ & $\begin{array}{l}\text { Kidney Tx } \\
\text { Acute } \\
\text { Tubular } \\
\text { Necrosis }\end{array}$ & BM-MSCs & $1 / 11$ & 120 & $\begin{array}{l}11 / 15 \\
- \\
12 / 17\end{array}$ & $\begin{array}{l}\text { Sun Yat-sen } \\
\text { University, } \\
\text { Guangzhou, China }\end{array}$ \\
\hline NCT00659620 & $\begin{array}{l}\text { Unknown } \\
\text { status }\end{array}$ & $\begin{array}{l}\text { Mesenchymal Stem Cell } \\
\text { Transplantation in the } \\
\text { Treatment of Chronic } \\
\text { Allograft Nephropathy }\end{array}$ & $\begin{array}{l}\text { Kidney Tx } \\
\text { Chronic } \\
\text { Allograft } \\
\text { Nephropath } \\
\text { y }\end{array}$ & MSC & $1 / I 1$ & 20 & $\begin{array}{l}05 / 08 \\
- \\
05 / 10\end{array}$ & $\begin{array}{l}\text { Fuzhou General } \\
\text { Hospital, Fuzhou, } \\
\text { China }\end{array}$ \\
\hline NCT00658073 & Completed & $\begin{array}{l}\text { Induction Therapy With } \\
\text { Autologous Mesenchymal } \\
\text { Stem Cells for Kidney } \\
\text { Allografts }\end{array}$ & $\begin{array}{l}\text { Kidney Tx } \\
\text { Rejection }\end{array}$ & MSCs infusion & NA & 165 & $\begin{array}{l}03 / 08 \\
- \\
10 / 10\end{array}$ & $\begin{array}{l}\text { General Hospital, } \\
\text { Fuzhou, China }\end{array}$ \\
\hline NCT03478215 & Recruiting & $\begin{array}{l}\text { Mesenchymal Stromal Cells } \\
\text { in Living Donor Kidney } \\
\text { Transplantation }\end{array}$ & Kidney Tx & MSCs Infusion & II & 24 & $\begin{array}{l}02 / 16 \\
- \\
07 / 21\end{array}$ & $\begin{array}{l}\text { Houston Methodist } \\
\text { Hospital System, } \\
\text { Houston, US }\end{array}$ \\
\hline NCT02492308 & $\begin{array}{l}\text { Unknown } \\
\text { status }\end{array}$ & $\begin{array}{l}\text { Induction With SVF Derived } \\
\text { MSC in Living-related } \\
\text { Kidney Transplantation }\end{array}$ & $\begin{array}{l}\text { Living- } \\
\text { relative } \\
\text { Kidney Tx }\end{array}$ & $\begin{array}{l}\text { SVF-MSC } \\
\text { induction }\end{array}$ & $\mathrm{I} / \mathrm{II}$ & 120 & $\begin{array}{l}12 / 14 \\
- \\
12 / 17\end{array}$ & Fuzhou, Fujian, China \\
\hline NCT02492490 & $\begin{array}{l}\text { Unknown } \\
\text { status }\end{array}$ & $\begin{array}{l}\text { Effect of SVF Derived MSC } \\
\text { in DCD Renal } \\
\text { Transplantation }\end{array}$ & Kidney Tx & $\begin{array}{l}\text { SVF derived } \\
\text { MSC }\end{array}$ & $\mathrm{I} / \mathrm{II}$ & 120 & $\begin{array}{l}12 / 14 \\
- \\
11 / 16\end{array}$ & $\begin{array}{l}\text { Fuzhou General } \\
\text { Hospital - Xiamen } \\
\text { Univ, Fuzhou, China }\end{array}$ \\
\hline NCT00734396 & Completed & $\begin{array}{l}\text { Mesenchymal Stem Cells } \\
\text { and Subclinical Rejection }\end{array}$ & $\begin{array}{l}\text { Organ } \\
\text { transplantat } \\
\text { ion }\end{array}$ & MSC infusion & $\mathrm{I} / \mathrm{II}$ & 15 & $\begin{array}{l}02 / 09 \\
- \\
07 / 16\end{array}$ & $\begin{array}{l}\text { Leiden University } \\
\text { Medical Center, } \\
\text { Leiden, Netherlands }\end{array}$ \\
\hline NCT01429038 & $\begin{array}{l}\text { Unknown } \\
\text { status }\end{array}$ & $\begin{array}{l}\text { Mesenchymal Stem Cells } \\
\text { After Renal or Liver } \\
\text { Transplantation }\end{array}$ & $\begin{array}{l}\text { Liver Tx } \\
\text { Kidney Tx }\end{array}$ & MSC & $\mathrm{I} / \mathrm{II}$ & 40 & $\begin{array}{l}02 / 12 \\
- \\
02 / 17\end{array}$ & $\begin{array}{l}\text { University Hospital } \\
\text { Liege, Liege, Belgium }\end{array}$ \\
\hline
\end{tabular}


Conflicting preclinical results exist regarding the application of allogeneic vs. autologous MSCs in the transplant setting. While some preclinical studies showed an accelerated graft rejection after allogeneic MSC administration [53, 54], others showed that allogeneic MSCs promote graft survival $[46,47]$. In vivo experiments showed that allogenic MSCs can induce memory T-cell [55] and the development of alloantibody formation [56]. Contrary to these data, Peng et al. [57] reported that renal transplant patients had stable transplant function following allogeneic MSC despite significant reduction of the tacrolimus dose. However, long-term data are missing and HLA-specific antibodies were not evaluated.

\section{Summary}

In recent years, the potential of hematopoietic stem cells, regulatory T-cells and mesenchymal stem cells resulted in a variety of clinical tolerance trials. Every approach has yielded promising results. The ongoing trials in this field will provide additional information regarding the risks and benefits of these therapy approaches.

\section{Abbreviations List}

$\mathrm{CNI}$ - Calcineurininhibitors; CKBMTx - combined kidney and bone marrow transplantation; CsA - Cyclosporine A; DC - dendritic cell; HSC - hematopietic stem cell; KTx - Kidney transplantation; MSC - mesenchymal stem cell; MMF - mycophenolate mofetil; RTx - renal transplantation; SRL Sirolimus; TAC - Tacrolimus; TBI - Total body irradiation; TLI - total lymphocyte irradiation; T reg regulatory $T$ cell.

\section{Author Contributions}

J. A. and A. H. contributed to the design, and writing of the manuscript.

\section{Competing Interests}

The authors have declared that no competing interests exist.

\section{References}

1. Hart A, Smith JM, Skeans MA, Gustafson SK, Wilk AR, Robinson A, et al. Optn/srtr 2016 annual data report: Kidney. Am J Transplant. 2018; 18: 18-113.

2. Billingham RE, Brent L, Medawar PB. Actively acquired tolerance of foreign cells. Nature. 1953; 172: 603-606.

3. Owen RD. Immunogenetic consequences of vascular anastomoses between bovine twins. Science. 1945; 102: 400.

4. Besancon A, Baas $M$, Goncalves $T$, Valette $F$, Waldmann $H$, Chatenoud L, et al. The induction and maintenance of transplant tolerance engages both regulatory and anergic CD4(+) T cells. Front Immunol. 2017; 8: 218.

5. Sakaguchi S, Sakaguchi N, Asano M, Itoh M, Toda M. Immunologic self-tolerance maintained by activated T cells expressing IL-2 receptor alpha-chains (CD25). Breakdown of a single 
mechanism of self-tolerance causes various autoimmune diseases. J Immunol. 1995; 155: 1151-1164.

6. Ochsenbein AF, Klenerman $P$, Karrer $U$, Ludewig B, Pericin $M$, Hengartner $H$, et al. Immune surveillance against a solid tumor fails because of immunological ignorance. Proc Natl Acad Sci U S A. 1999; 96: 2233-2238.

7. Sarraj B, Ye J, Akl Al, Chen G, Wang JJ, Zhang Z, et al. Impaired selectin-dependent leukocyte recruitment induces T-cell exhaustion and prevents chronic allograft vasculopathy and rejection. Proc Natl Acad Sci U S A. 2014; 111: 12145-12150.

8. Wells AD, Li XC, Li Y, Walsh MC, Zheng XX, Wu Z, et al. Requirement for T-cell apoptosis in the induction of peripheral transplantation tolerance. Nat Med. 1999; 5: 1303-1307.

9. Kawai T, Sachs DH, Sprangers B, Spitzer TR, Saidman SL, Zorn E, et al. Long-term results in recipients of combined HLA-mismatched kidney and bone marrow transplantation without maintenance immunosuppression. Am J Transplant. 2014; 14: 1599-1611.

10. Spitzer TR, Sykes M, Tolkoff-Rubin N, Kawai T, McAfee SL, Dey BR, et al. Long-term follow-up of recipients of combined human leukocyte antigen-matched bone marrow and kidney transplantation for multiple myeloma with end-stage renal disease. Transplantation. 2011; 91: 672-676.

11. Scandling JD, Busque S, Shizuru JA, Lowsky R, Hoppe R, Dejbakhsh-Jones S, et al. Chimerism, graft survival, and withdrawal of immunosuppressive drugs in HLA matched and mismatched patients after living donor kidney and hematopoietic cell transplantation. Am J Transplant. 2015; 15: 695-704.

12. Leventhal JR, Elliott MJ, Yolcu ES, Bozulic LD, Tollerud DJ, Mathew JM, et al. Immune reconstitution/immunocompetence in recipients of kidney plus hematopoietic stem/facilitating cell transplants. Transplantation. 2015; 99: 288-298.

13. Scandling JD, Busque S, Lowsky R, Shizuru J, Shori A, Engleman E, et al. Macrochimerism and clinical transplant tolerance. Hum Immunol. 2018; 79: 266-271.

14. Huang Y, Elliott MJ, Yolcu ES, Miller TO, Ratajczak J, Bozulic LD, et al. Characterization of human CD8(+)TCR(-) facilitating cells in vitro and in vivo in a nod/scid/IL2rgamma(null) mouse model. Am J Transplant. 2016; 16: 440-453.

15. Leventhal JR, Ildstad ST. Tolerance induction in HLA disparate living donor kidney transplantation by facilitating cell-enriched donor stem cell infusion: The importance of durable chimerism. Hum Immunol. 2018; 79: 272-276.

16. Leventhal JR, Miller J, Mathew JM, Kurian S, Tambur AR, Friedewald J, et al. Updated followup of a tolerance protocol in HLA-identical renal transplant pairs given donor hematopoietic stem cells. Hum Immunol. 2018; 79: 277-282.

17. Hori S, Nomura T, Sakaguchi S. Control of regulatory T cell development by the transcription factor FOXP3. Science. 2003; 299: 1057-1061.

18. Fontenot JD, Gavin MA, Rudensky AY. FOXP3 programs the development and function of CD4+CD25+ regulatory T cells. Nat Immunol. 2003; 4: 330-336.

19. Wood KJ, Bushell A, Hester J. Regulatory immune cells in transplantation. Nat Rev Immunol. 2012; 12: 417-430.

20. Salama AD, Najafian N, Clarkson MR, Harmon WE, Sayegh MH. Regulatory CD25+ T cells in human kidney transplant recipients. J Am Soc Nephrol. 2003; 14: 1643-1651. 
21. Schmidt A, Oberle N, Krammer PH. Molecular mechanisms of Treg-mediated T cell suppression. Front Immunol. 2012; 3: 51.

22. Vignali DA, Collison LW, Workman CJ. How regulatory T cells work. Nat Rev Immunol. 2008; 8: 523-532.

23. Lee K, Nguyen V, Lee KM, Kang SM, Tang Q. Attenuation of donor-reactive T cells allows effective control of allograft rejection using regulatory T cell therapy. Am J Transplant. 2014; 14: 27-38.

24. Tang Q, Vincenti F. Transplant trials with Tregs: Perils and promises. J Clin Invest. 2017; 127: 2505-2512.

25. Hall BM. T cells: Soldiers and spies--the surveillance and control of effector $\mathrm{T}$ cells by regulatory T cells. Clin J Am Soc Nephrol. 2015; 10: 2050-2064.

26. Hoffmann P, Boeld TJ, Eder R, Huehn J, Floess S, Wieczorek G, et al. Loss of FOXP3 expression in natural human $\mathrm{CD} 4+\mathrm{CD} 25+$ regulatory $\mathrm{T}$ cells upon repetitive in vitro stimulation. Eur J Immunol. 2009; 39: 1088-1097.

27. Liu W, Putnam AL, Xu-Yu Z, Szot GL, Lee MR, Zhu S, et al. CD127 expression inversely correlates with FOXP3 and suppressive function of human CD4+ T reg cells. J Exp Med. 2006; 203: 1701-1711.

28. Peters JH, Preijers FW, Woestenenk R, Hilbrands LB, Koenen HJ, Joosten I. Clinical grade Treg: Gmp isolation, improvement of purity by CD127 depletion, Treg expansion, and Treg cryopreservation. PLoS One. 2008; 3: e3161.

29. Rudensky AY. Regulatory T cells and FOXP3. Immunol Rev. 2011; 241: 260-268.

30. Bashuda H, Kimikawa M, Seino K, Kato Y, Ono F, Shimizu A, et al. Renal allograft rejection is prevented by adoptive transfer of anergic T cells in nonhuman primates. J Clin Invest. 2005; 115: 1896-1902.

31. Brunstein CG, Miller JS, Cao Q, McKenna DH, Hippen KL, Curtsinger J, et al. Infusion of ex vivo expanded $\mathrm{T}$ regulatory cells in adults transplanted with umbilical cord blood: Safety profile and detection kinetics. Blood. 2011; 117: 1061-1070.

32. Di lanni M, Del Papa B, Cecchini D, Bonifacio E, Moretti L, Zei T, et al. Immunomagnetic isolation of CD4+CD25+FOXP3+ natural T regulatory lymphocytes for clinical applications. Clin Exp Immunol. 2009; 156: 246-253.

33. Marek-Trzonkowska N, Mysliwec M, Siebert J, Trzonkowski P. Clinical application of regulatory T cells in type 1 diabetes. Pediatr Diabetes. 2013; 14: 322-332.

34. Chandran S, Tang Q, Sarwal M, Laszik ZG, Putnam AL, Lee K, et al. Polyclonal regulatory T cell therapy for control of inflammation in kidney transplants. Am J Transplant. 2017; 17: 29452954.

35. Mathew JM, J HV, LeFever A, Konieczna I, Stratton C, He J, et al. A phase i clinical trial with ex vivo expanded recipient regulatory T cells in living donor kidney transplants. Sci Rep. 2018; 8: 7428.

36. Todo S, Yamashita K, Goto R, Zaitsu M, Nagatsu A, Oura T, et al. A pilot study of operational tolerance with a regulatory T-cell-based cell therapy in living donor liver transplantation. Hepatology. 2016; 64: 632-643.

37. Koyama I. Induction of donor specific hyporesponsiveness in kidney transplantation using adoptive transfer of ex vivo induced tolerogenic cells. Am J Transplant. 2013; 13. 
38. Le Blanc K, Rasmusson I, Sundberg B, Gotherstrom C, Hassan M, Uzunel M, et al. Treatment of severe acute graft-versus-host disease with third party haploidentical mesenchymal stem cells. Lancet. 2004; 363: 1439-1441.

39. da Silva Meirelles L, Chagastelles PC, Nardi NB. Mesenchymal stem cells reside in virtually all post-natal organs and tissues. J Cell Sci. 2006; 119: 2204-2213.

40. Dominici M, Le Blanc K, Mueller I, Slaper-Cortenbach I, Marini F, Krause D, et al. Minimal criteria for defining multipotent mesenchymal stromal cells. The international society for cellular therapy position statement. Cytotherapy. 2006; 8: 315-317.

41. Garakani R, Saidi RF. Recent progress in cell therapy in solid organ transplantation. Int J Organ Transplant Med. 2017; 8: 125-131.

42. Beyth S, Borovsky Z, Mevorach D, Liebergall M, Gazit Z, Aslan H, et al. Human mesenchymal stem cells alter antigen-presenting cell maturation and induce T-cell unresponsiveness. Blood. 2005; 105: 2214-2219.

43. Casiraghi F, Perico N, Remuzzi G. Mesenchymal stromal cells for tolerance induction in organ transplantation. Hum Immunol. 2018; 79: 304-313.

44. Ge W, Jiang J, Arp J, Liu W, Garcia B, Wang H. Regulatory T-cell generation and kidney allograft tolerance induced by mesenchymal stem cells associated with indoleamine 2,3dioxygenase expression. Transplantation. 2010; 90: 1312-1320.

45. Griffin MD, Elliman SJ, Cahill E, English K, Ceredig R, Ritter T. Concise review: Adult mesenchymal stromal cell therapy for inflammatory diseases: How well are we joining the dots? Stem Cells. 2013; 31: 2033-2041.

46. Eggenhofer E, Steinmann JF, Renner P, Slowik P, Piso P, Geissler EK, et al. Mesenchymal stem cells together with mycophenolate mofetil inhibit antigen presenting cell and $\mathrm{T}$ cell infiltration into allogeneic heart grafts. Transplant Immunol. 2011; 24: 157-163.

47. Ge W, Jiang J, Baroja ML, Arp J, Zassoko R, Liu W, et al. Infusion of mesenchymal stem cells and rapamycin synergize to attenuate alloimmune responses and promote cardiac allograft tolerance. Am J Transplant. 2009; 9: 1760-1772.

48. Tan J, Wu W, Xu X, Liao L, Zheng F, Messinger S, et al. Induction therapy with autologous mesenchymal stem cells in living-related kidney transplants: A randomized controlled trial. JAMA. 2012; 307: 1169-1177.

49. Reinders ME, de Fijter JW, Roelofs H, Bajema IM, de Vries DK, Schaapherder AF, et al. Autologous bone marrow-derived mesenchymal stromal cells for the treatment of allograft rejection after renal transplantation: Results of a phase i study. Stem Cells Transl Med. 2013; 2: 107-111.

50. Perico N, Casiraghi F, Introna M, Gotti E, Todeschini M, Cavinato RA, et al. Autologous mesenchymal stromal cells and kidney transplantation: A pilot study of safety and clinical feasibility. Clin J Am Soc Nephrol. 2011; 6: 412-422.

51. Perico N, Casiraghi F, Gotti E, Introna M, Todeschini M, Cavinato RA, et al. Mesenchymal stromal cells and kidney transplantation: Pretransplant infusion protects from graft dysfunction while fostering immunoregulation. Transplant Int. 2013; 26: 867-878.

52. Vanikar AV, Trivedi HL, Thakkar UG. Six years' experience of tolerance induction in renal transplantation using stem cell therapy. Clin Immunol. 2018; 187: 10-14. 
53. Griffin MD, Ryan AE, Alagesan $S$, Lohan $P$, Treacy $O$, Ritter $T$. Anti-donor immune responses elicited by allogeneic mesenchymal stem cells: What have we learned so far? Immunol Cell Biol. 2013; 91: 40-51.

54. Reinders ME, Dreyer GJ, Bank JR, Roelofs H, Heidt S, Roelen DL, et al. Safety of allogeneic bone marrow derived mesenchymal stromal cell therapy in renal transplant recipients: The neptune study. J Transl Med. 2015; 13: 344.

55. Zangi L, Margalit R, Reich-Zeliger S, Bachar-Lustig E, Beilhack A, Negrin R, et al. Direct imaging of immune rejection and memory induction by allogeneic mesenchymal stromal cells. Stem Cells. 2009; 27: 2865-2874.

56. Badillo AT, Beggs KJ, Javazon EH, Tebbets JC, Flake AW. Murine bone marrow stromal progenitor cells elicit an in vivo cellular and humoral alloimmune response. Biol Blood Marrow Transplant. 2007; 13: 412-422.

57. Peng $Y, K e M, X u L$, Liu L, Chen $X, X i a ~ W$, et al. Donor-derived mesenchymal stem cells combined with low-dose tacrolimus prevent acute rejection after renal transplantation: $A$ clinical pilot study. Transplantation. 2013; 95: 161-168.

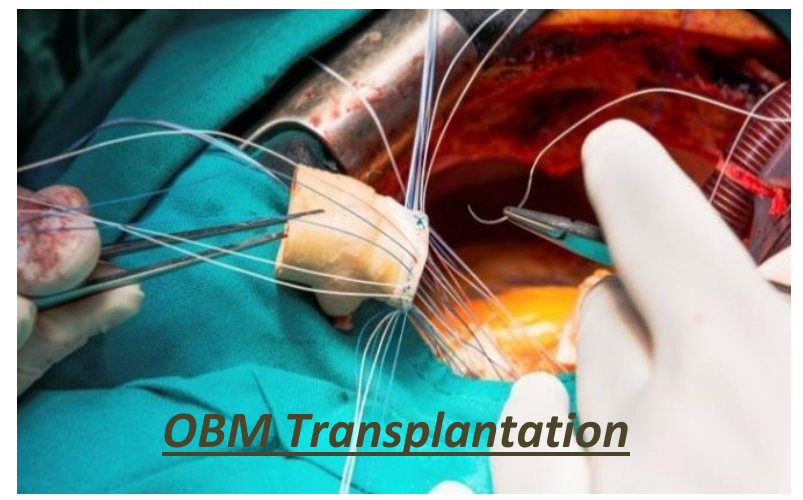

Enjoy OBM Transplantation by:

1. Submitting a manuscript

2. Joining in volunteer reviewer bank

3. Joining Editorial Board

4. Guest editing a special issue

For more details, please visit:

http://www.lidsen.com/journals/transplantation 